\title{
Modeling of Battery Electric Vehicles for Degradation Studies
}

\author{
Calearo, Lisa; Thingvad, Andreas; Marinelli, Mattia
}

Published in:

Proceedings of the 54th International Universities Power Engineering Conference

Link to article, DOI:

10.1109/upec.2019.8893474

Publication date:

2019

Document Version

Peer reviewed version

Link back to DTU Orbit

Citation (APA):

Calearo, L., Thingvad, A., \& Marinelli, M. (2019). Modeling of Battery Electric Vehicles for Degradation Studies. In Proceedings of the 54th International Universities Power Engineering Conference [8893474] IEEE. https://doi.org/10.1109/upec.2019.8893474

\section{General rights}

Copyright and moral rights for the publications made accessible in the public portal are retained by the authors and/or other copyright owners and it is a condition of accessing publications that users recognise and abide by the legal requirements associated with these rights.

- Users may download and print one copy of any publication from the public portal for the purpose of private study or research.

- You may not further distribute the material or use it for any profit-making activity or commercial gain

- You may freely distribute the URL identifying the publication in the public portal

If you believe that this document breaches copyright please contact us providing details, and we will remove access to the work immediately and investigate your claim 


\title{
Modeling of Battery Electric Vehicles for Degradation Studies
}

\author{
Lisa Calearo, Andreas Thingvad and Mattia Marinelli \\ Center for Electric Power and Energy, Department of Electrical Engineering, \\ Technical University of Denmark (DTU) \\ Ris $\emptyset$ Campus, Roskilde, Denmark \\ $\{$ lica, athing, matm\}@elektro.dtu.dk
}

\begin{abstract}
The paper characterizes dynamics and modelling of a Lithium-ion battery. Theoretical formulation and literature review are combined to derive the necessary battery characterization. The three main dynamics for modeling the battery are: direct-current electrical equivalent circuit, state-ofcharge (SOC) and thermal dynamic. Furthermore, the capacity fade caused by degradation is considered as a fourth dynamic. Degradation is considered as the sum of calendar aging and cycling loss dynamics. The modeling procedure has general validity and can be used for different battery chemistries by changing specific parameters. The model is tailored for a 40 kWh Lithium Nickel Manganese Cobalt (NMC) Oxide battery, which is currently used in the Nissan LEAF 2018. Considering a user driving $45 \mathrm{~km} /$ day and the temperature of the years 2017 and 2018 in Denmark, the battery capacity fade is found to be between 2 and $5 \%$ of the battery capacity after two years of use. Degradation is highly dependent on the average level of SOC during the years.
\end{abstract}

Index Terms--Electric Vehicles, NMC Batteries, ThermoElectrical Model, Capacity Fade.

\section{INTRODUCTION}

The battery is the key for the electrification of the transport sector. A battery pack is composed of modules of cells, which, depending on the electric vehicle $(\mathrm{EV})$ model, are differently organized into the battery pack. In literature many authors modelled the characteristics of EV batteries with different main interests. In [1] the authors focused on the dynamic characteristics of the battery pack during charging and discharging, in [2] the thermal model for the pouch Lithium ion battery cells was developed based on experimental analyses, in [3]-[5] the authors focused on calendar aging and cycling loss characterization. In [4], [6] the authors analyzed the calendar and cycling loss related to vehicle-to-grid (V2G) services. This paper aims at modelling the battery of an EV from the electrical circuit representation to the thermal characterization, including the capacity fade description. The authors aim at modeling the battery of an EV to analyze the degradation of the battery in different scenarios. The model is of high importance for the EV users, which should know how their battery is going to perform during its lifetime. At the same time, a good understanding of the different degradation mechanisms enables the EV owner to minimize the degradation by adjusting the usage pattern. The storage model consists of three dynamics: state-of-charge (SOC), electrochemical model and thermal characterization. The battery pack is made of cells in series and parallel to achieve the wanted voltage and energy capacity. The thermal dynamic of a single cell can be modeled in a straightforward way. However, in a battery pack, the thermal characteristic of the individual cells depends on the location and temperature of the neighboring cells which increase the modelling complexity. A fourth dynamic is the capacity fade of the battery, which is the sum of calendar aging and cycling losses. The capacity fade is described in detailed in the paper and it is implemented on the model for degradation analyses.

This paper is organized as follows. In Section II a battery model overview, with theoretical electro and thermal characterization, is provided. Section III describes in detail the electrochemical dynamics. Thermal modeling is discussed in Section IV, while degradation is discussed in Section V. Section VI analyzes the performance of the model considering an average EV user behavior and Section VII concludes the article with the main outcomes.

\section{BATTERy MODEL OVERVIEW}

The battery is characterized by three main dynamics: SOC, electrochemical conversion and thermal dynamics. These three dynamics are related to three main variables: SOC, temperature and voltage, see Figure 1 . The three dynamics can be briefly described as:

- The Direct Current (DC) electrical equivalent circuit is used to model the battery current, voltage and internal electrical resistance.

- The thermodynamics describes the temperature of the battery as it is heated up by joule losses as a function of the current and the internal resistance and when it releases heat to environment as a function of the outside temperature and the thermal resistance. 
- The SOC describes the energy content at the battery at the specific time where $0 \%=$ empty and $100 \%=$ full. The energy charged or discharged is divided with the remaining battery capacity to calculate the change in SOC.

The battery capacity fade is a function of irreversible electrochemical side-reactions [7], which causes the energy capacity to decrease. These losses can be divided into calendar aging and cycling aging. The first one is function of time, temperature and SOC, and it is present even when the battery is not used. The second one is the degradation of the battery caused by cycling (charging and discharging). It is function of temperature, energy throughput in terms of full equivalent charge cycles from $0-100 \%$ and the C-rate of the current.

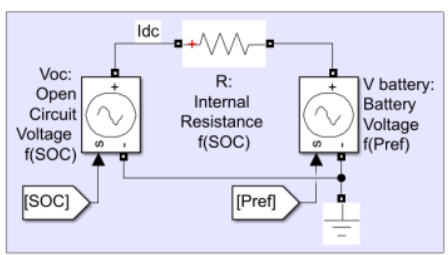

ELECTRO-CHEMICAL DYNAMIC

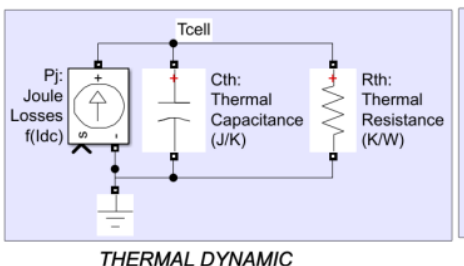

THERMAL DYNAMIC

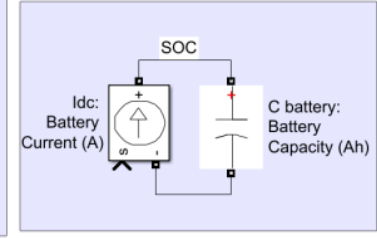

SOC DYNAMIC

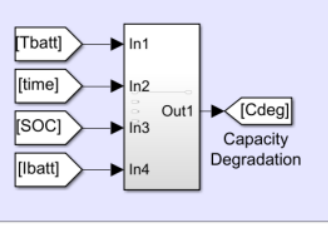

DEGRADATION DYNAMIC
Figure 1. Battery model representation. Adapted from [8].

\section{ELECTROCHEMICAL MODELLING}

\section{A. Battery Characterization}

This paper analyses the battery present in the Nissan LEAF $40 \mathrm{kWh}$, consisting of Lithium Nickel Manganese Cobalt Oxide (NMC) prismatic/pouch cells. The cells are combined into 24 modules, each one with 8 cells, which are grouped into the battery pack, see Figure 2. Figure 3 provides the cell and module characterizations. This EV and the battery size are chosen because they represent the average storage of EVs in a near future, since the battery is able to provide the needs of users in various countries [9], [10].

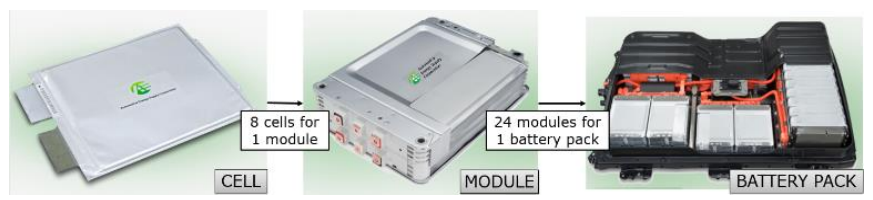

Figure 2. From the single cell to the battery pack. Adapted from Nissan.

\begin{tabular}{|c|c|c|c|c|c|}
\hline \multicolumn{3}{|c|}{$\mathrm{C} e I 1$} & \multicolumn{3}{|c|}{ Module } \\
\hline \multirow{2}{*}{\multicolumn{2}{|c|}{$\begin{array}{l}\text { Rated capacity } \\
\text { Nominal voltage }\end{array}$}} & $56.3 \mathrm{Ah}$ & \multicolumn{2}{|c|}{ Number of cells } & \multirow[t]{2}{*}{8} \\
\hline & & $3.65 \mathrm{~V}$ & & & \\
\hline \multirow{4}{*}{$\begin{array}{l}\text { External } \\
\text { dimensions }\end{array}$} & Length & $261 \mathrm{~mm}$ & \multirow{4}{*}{$\begin{array}{l}\text { External } \\
\text { dimensions }\end{array}$} & Length & $300 \mathrm{~mm}$ \\
\hline & Width & $216 \mathrm{~mm}$ & & Width & $222 \mathrm{~mm}$ \\
\hline & Thickness & $7.91 \mathrm{~mm}$ & & Thickness & $68 \mathrm{~mm}$ \\
\hline & Mass & $914 \mathrm{~g}$ & & Mass & $8.7 \mathrm{~kg}$ \\
\hline
\end{tabular}

Figure 3. Cell and module characteristics. Adapted from Nissan.
In the Nissan LEAF 2018 the total number of cells $\left(N_{\text {cells }}\right)$ is equal to 192, divided into series of 96 cells $\left(N_{\text {cellss }}\right)$ and parallel $\left(N_{\text {cells }} P\right)$ of 2 cells. The battery has a capacity of 40 $k W h$, a nominal voltage of the single cell $\left(V_{\text {nomcell }}=3.65 \mathrm{~V}\right)$ and a nominal current capacity $\left(I_{\text {nomcell }}=56.3 \mathrm{Ah}\right)$. The nominal voltage of the battery pack is:

$$
V_{\text {nombatt }}=V_{\text {nomcell }} \times N_{\text {cellss }}=3.65 \mathrm{~V} * 96=350 \mathrm{~V}
$$

The initial current capacity $\left(C^{i}\right.$ batt $)$ of the battery pack is:

$$
C_{\text {batt }}^{i}=C_{\text {cell }} \times N_{\text {cells }}=56.3 \mathrm{Ah} \times 2=112.6 \mathrm{Ah}
$$

This is the initial battery capacity, which over time is reduced by degradation, as presented in Section V.

\section{B. DC electrical equivalent circuit}

The DC electrical equivalent dynamic is based on Ohm's law. The current $\left(I_{\text {batt }}\right)$ and voltage $\left(V_{\text {batt }}\right)$ of the battery are determined solving the system of (3)-(4):

$$
\begin{aligned}
& V_{\text {batt }}=V_{\text {oc }}-I_{\text {batt }} \times R_{\text {batt }} \\
& P_{\text {batt }}=V_{\text {batt }} \times I_{\text {batt }}
\end{aligned}
$$

Where $P_{\text {batt }}$ is the power flowing into the battery, $V_{o c}$ is the open circuit voltage and $R_{b a t t}$ the electrical resistance of the battery. In this formulation when $I_{\text {batt }}$ is negative the battery is charging and when positive it is discharging. $V_{o c}$ is the sum of the open circuit voltage of all the cells $\left(V_{\text {occell }}\right)$ in series:

$$
V_{o c}=V_{\text {occell }} \times N_{\text {cellss }}
$$

$V_{\text {occell }}$ is function of the SOC of the cell. The SOC of all the cells are considered identical as they are assumed to have experienced the same amount of degradation. The $V_{\text {occell }}-S O C$ relation considered in this paper is the one of a Kokam $53 \mathrm{Ah}$ SPLB 120216216 Li-ion NMC pouch cell [11] when the temperature is equal to $25 \mathrm{deg}$. The voltage curve of Kokam $53 \mathrm{Ah}$, reported in Figure 4, is used because the open circuit voltage and the internal resistance of 56.3 Ah are not publicly available.

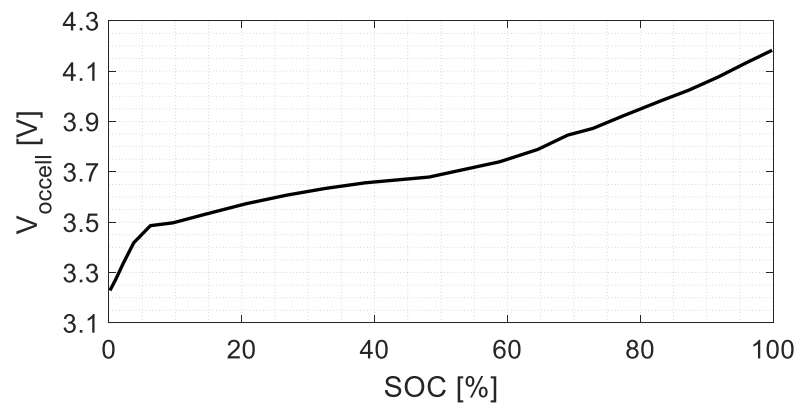

Figure 4. Experimental Voccell-SOC curves NMC cells. Adapted from [11]. 
Lithium ion cells can only be operated safely in a specific voltage range from $3-4.2 \mathrm{~V}$, so in the simulation the following saturation is considered:

$$
3 \mathrm{~V} \times N_{\text {cellss }} \leq V_{\text {batt }} \leq 4.2 \mathrm{~V} \times N_{\text {cells }}
$$

$R_{\text {batt }}$ is found by adding the resistance of the series connected cells and calculating the parallel resistance of the parallel connected cells. Since we are assuming that all the cell resistances are equal; for equal resistances in parallel, the expression simplifies to:

$$
R_{\text {batt }}=R_{\text {cell }} \times N_{\text {cellss }} / N_{\text {cellsP }}
$$

$R_{\text {cell }}$ here considered is the one of the Kokam 56.3 Ah NMC cell [11], which is provided in Figure 5. The figure shows $R_{\text {cell }}$ during three different measurements. $R_{c h}$ and $R_{\text {disch }}$ is the resistance derived with pulse power characterization test at $25{ }^{\circ} \mathrm{C}$ and $\mathrm{C}$ rate of 0.5 . A $\mathrm{C}$ rate equal to 0.5 implies a current flow equal to $50 \%$ the nominal. It can be appreciated as the direction of the current has no significant influence. Temperature on the other hand can affect the internal resistance value, but at this stage of the model, $25^{\circ} \mathrm{C}$ is considered to be a representative average temperature..

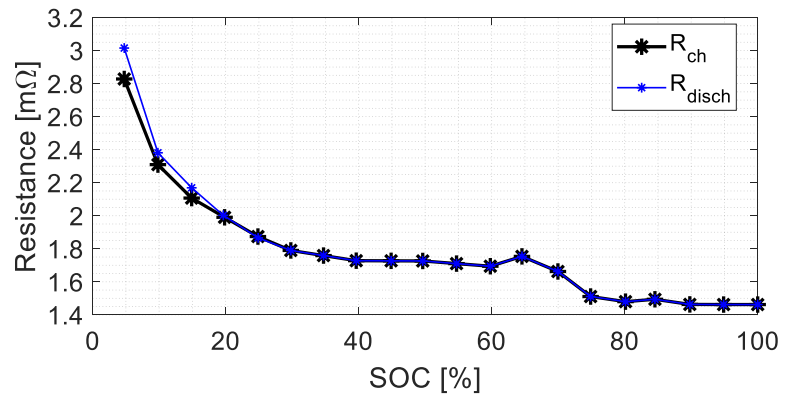

Figure 5. Resistance of the single-cell Li-ion battery from open circuit voltage tests at 25 degrees. Adapted from [11]

\section{State-of-charge (SOC) dynamic}

The SOC is found by integrating the the current flowing in the battery over time:

$$
I_{\text {batt }}=C_{\text {batt }} \times d S O C / d t
$$

Where $\operatorname{SOC}(0)=S O C_{0}$

$$
\operatorname{SOC}(t)=\int-I_{\text {batt }} / C_{b a t t} d t
$$

$C_{\text {batt }}$ decreases over time and it is here calculated by subtracting the calendar loss and cycle loss from the initial capacity:

$$
C_{b a t t}=C_{b a t t}^{i}-\left(Q_{c a l}+Q_{c y c l e}\right) / 100 \times C_{b a t t}^{i}
$$

With $Q_{\text {cal }}$ the calendar loss and $Q_{c y c l e}$ the cycling loss in percent of the initial capacity, as presented in Section V.

\section{THERMAL MODELLING}

\section{A. Equivalent dynamic}

The thermal dynamic model defines the inner temperature of the battery $\left(T_{\text {batt }}\right) . T_{\text {batt }}$ is function of the outside temperature $\left(T_{\text {out }}\right)$ and the joule losses $\left(P_{j}\right)$ of the battery. The lumped capacitance thermal network of the battery and its environment are defined as in (11):

$$
C_{\text {th }} d T_{\text {bat }} / d t=1 / R_{\text {th }} \times\left(T_{\text {out }}-T_{\text {batt }}\right)+P_{j}
$$

In this formulation the cabin and outside temperatures are considered the same. In case of a deeper detailed model, two levels of heat would be: the heat dissipating from the cell to the pack and the heat dissipating from the pack to the out door. Thus cabin and outside temperatures are different as in (12) [4]:

$1 / R_{\text {th }} \times\left(T_{\text {out }}-T_{\text {batt }}\right)=1 / R_{\text {th }} \times\left(T_{\text {out }}-T_{\text {cab }}\right)+1 / R_{\text {th }} \times\left(T_{\text {cab }}-T_{\text {batt }}\right)(12)$

The joule losses generated by the battery are as in (13):

$$
P_{j}=I_{\text {batt }}^{2} \times R_{\text {batt }}
$$

$C_{t h}$ is the thermal capacitance of the battery, $R_{t h}$ is the thermal resistance of the battery.

\section{B. Thermal capacitance}

The thermal capacitance of the cell and of the entire battery $\left(C_{t h}\right)$ are defined in (14)-(15):

$$
\begin{aligned}
& C_{\text {thcell }}=c_{\text {Pcell }} \times m_{\text {cell }} \\
& C_{\text {thbatt }}=c_{\text {Pbatt }} \times m_{\text {batt }}
\end{aligned}
$$

First in (14) the $C_{\text {thcell }}$ is derived for the single cell, where $c_{P c e l l}$ is the specific heat capacity at constant pressure of the single cell. $c_{P}$ of a cell is defined as the sum of the heat capacity of each cell components [2][12]. The cells are grouped into modules and the modules form the battery pack, with a minimization of the surrounding materials to maximize the thermal losses. It is therefore assumed the same heat capacity for the single cell as for the whole battery and with $m_{\text {batt }}$ the battery weight, the $C_{\text {thbatt }}$ is determined in (18). The $c_{P}$ of a NMC Lithium ion pouch cell is found to be in the range $700-1300 \mathrm{~J} /(\mathrm{kg} \mathrm{K})$ [2], [13], [14].

In [13], the $c_{P}=1100 \mathrm{~J} /(\mathrm{kg} \mathrm{K})$ is considered for a $53 \mathrm{Ah}$ NMC pouch cell. Due to the unknown volume of each component of the battery, the specific heat capacity of the entire battery is considered to be the same of the single cell. The present battery has 24 modules, each one of $8.7 \mathrm{~kg}$ with a total battery weight of:

$$
m_{\text {batt }}=8.7 \mathrm{~kg} \times 24=208.8 \mathrm{~kg}
$$

The $C_{t h}$ is thus: 


$$
C_{t h}=1100 \mathrm{~J} /(\mathrm{kg} \mathrm{K}) \times 208.8 \mathrm{~kg}=229680 \mathrm{~J} / \mathrm{K}
$$

\section{Thermal resistance}

Considering a single pouch cell, the heat transfer is usually considered only in the $\mathrm{z}$-axis direction, due to the fact that through $\mathrm{x}$ - and $\mathrm{y}$ - axes the cell would dissipate much less than in $\mathrm{z}$-axis. The thermal resistance on the $\mathrm{z}$-axis is:

$$
R_{\text {thcell }}=\left(\text { thick } k_{\text {cell }} / 2\right) /\left(2 \times S_{\text {cell }} \times k\right)
$$

With thick $k_{\text {cell }}$ the thickness of the cell and $k$ the heat transfer coefficient of the single cell. For the considered NMC cell the thermal resistance is:

$$
\begin{gathered}
R_{\text {thcell }}=(0.00791 / 2) /(2 \times 0.261 \times 0.261 \times 0.48) \\
R_{\text {thcell }}=0.073 \mathrm{~K} / \mathrm{W}
\end{gathered}
$$

Differently from the electrical resistance, the thermal resistance is not only function of the series and parallel between the cells, but also of the cells disposition in the modules/battery pack. In this model it is assumed that the temperature of the entire pack is homogeneous.
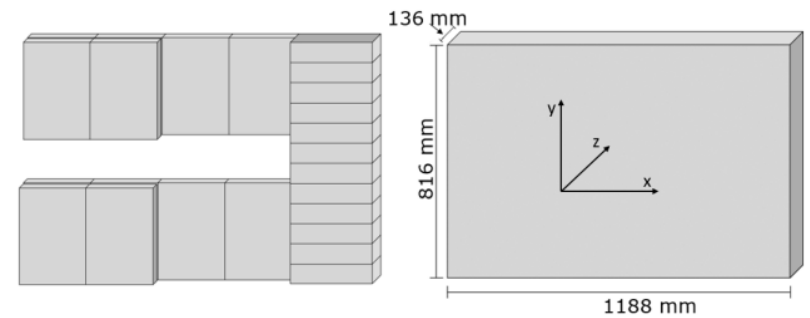

Figure 6. a. Battery pack modules disposition. b. Battery pack simplification for heat transfer analysis.

To determine the thermal resistance of the entire battery pack, the shape of the battery, shown in Figure $6 \mathrm{a}$, is simplified as in Figure 6b. This simplification is necessary to apply to the whole battery the same formulation used for the single cell. Differently from the single pouch cell, for the battery pack all the three directions $\mathrm{z}-$, $\mathrm{y}$ - and $\mathrm{x}$ - could be relevant in terms of thermal resistance. Therefore the $R_{\text {thbat }}$ is here evaluated for the three axis:

$$
\begin{gathered}
R_{\text {thbatt } Z}=(0.136 / 2) /(2 \times 0.816 \times 1.188 \times 0.48)=0.073 \mathrm{~K} / \mathrm{W}(21) \\
R_{\text {thbatt } X}=(1.188 \times 2) /(4 \times 0.816 \times 0.136 \times 0.48)=5.58 \mathrm{~K} / \mathrm{W}(22) \\
R_{\text {thbatt } Y}=(0.816) /(4 \times 1.188 \times 0.136 \times 0.48)=2.63 \mathrm{~K} / \mathrm{W}(23)
\end{gathered}
$$

Being $R_{\text {thbatt } Y}=76 \times R_{\text {thbattZ }}$ and $R_{\text {thbatt } X}=36 \times R_{\text {thbatt }}$, similar to the case of the single cell, the total resistance of the battery is approximated as well to the $R_{\text {thbattz. }}$.

Considering the evaluated $C_{t h}$ and $R_{t h}$, the thermal constant is calculated:

$$
3 \tau=3 \times R_{t h} \times C_{t h}=3 \times 0.0731 \times 229680=50353 \mathrm{sec}(25)
$$

$3 \tau$ is equal to 14 hours, time the battery would need for going back to $95 \%$ of the outside temperature which is calculated based on dimension and weight of the considered battery.

\section{DEGRADATION MODELLING}

\section{A. Equivalent Dynamic}

The battery capacity fade, sum of calendar and cycling loss, is a function of the thermal and SOC dynamics of the battery as shown in:

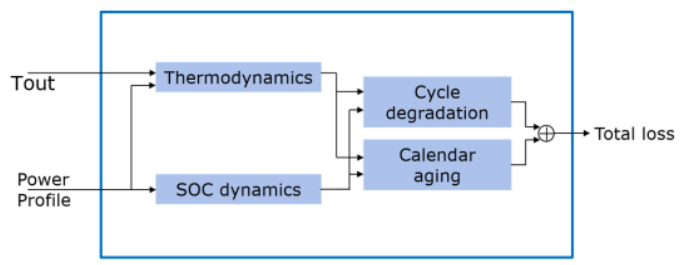

Figure 7. Battery representation with input data, parameters and output data of degradation model. Modified from [10].

\section{B. Calendar loss}

The instantaneous calendar loss $\left(Q^{\text {ist }}\right.$ loss $)$ is estimated using the fitted Arrhenius equation in (26) [4]:

$$
Q^{i s t}{ }_{\text {loss }}(t)=f \times \exp \left(-E_{a} /(R T)\right) \times t^{0.5}
$$

Where $Q^{i s t}$ loss is the percentage of capacity loss induced by calendar aging, $f$ is the pre-exponential factor, which is 14876 day $^{0.5}$ [4]. $E_{a}$ is the activation energy equal to $24.5 \mathrm{~kJ} \mathrm{~mol}^{-1} . R$ is the gas constant equal to $8.314 \mathrm{~J} \mathrm{~mol}^{-1} K^{-1} . T$ is the absolute temperature in $K$.

The accumulated calendar loss is determined as difference between the instantaneous calendar loss at time $t$ and at time $t-\Delta t$ as in (27)

$$
\begin{gathered}
Q_{\text {loss }}=1 / \Delta t \times \int\left(Q^{\text {ist }} \text { loss }(t)-Q^{i s t} \text { loss }(t-\Delta t)\right) \mathrm{dt}=1 / \Delta t \times \int[f \times \\
\left.\exp \left(-E_{a} /(R T)\right) \times t^{0.5}\right]-\left[f \times \exp \left(-E_{a} /(R T)\right) \times(t-\Delta t)^{0.5}\right] d t
\end{gathered}
$$

$f$ is defined in [4] as a constant value. Nevertheless, as it can be seen in Figure 8 it is not straightforward to describe $f$ with a single equation since it is a non-linear function of both SOC and temperature.

Isolating $f$ from (26) into (28), considering $t$ in days:

$$
f=Q^{i s t} \text { loss }(t) /\left(\exp \left(-E_{a} /(R T)\right) \times \text { days }^{0.5}\right)
$$

the $f$ values are evaluated considering 300 days, $T$ equal to 25,40 and $50{ }^{\circ} \mathrm{C}$, and the $Q_{\text {loss }}$ derived from the SOC and Figure 8.

$$
\tau=R_{t h} \times C_{t h}
$$




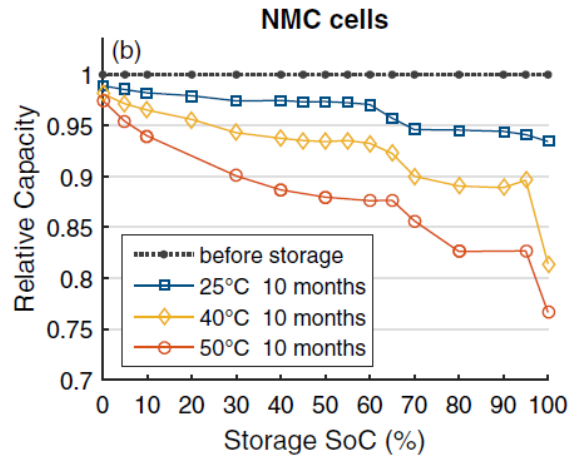

Figure 8. Relative capacity of the NMC cells in function of the SOC and temperature after 10 months lifetime from [3].

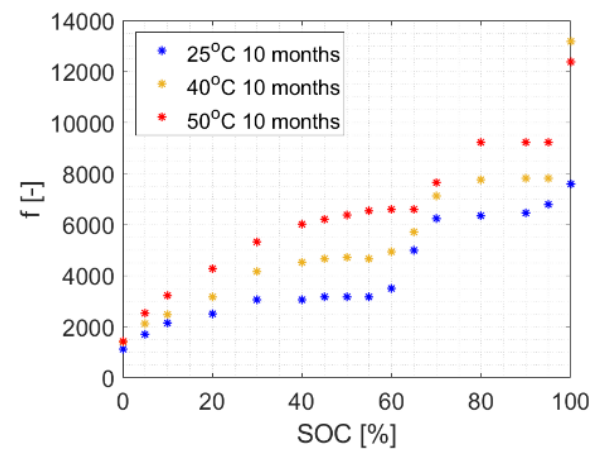

Figure 9. f representation with 300 days, increasing SOC and different temperatures.

For simplicity only the fitting with $25^{\circ} \mathrm{C}$ is considered, as it has a higher occurrence similar to the outside temperature in European countries.

As seen in Figure 9 it is not possible to make a low order representation of $f$ without making a curve for different sections of the SOC, thus:

$$
\begin{gathered}
f_{25}=-1.0353 \times S^{2} O^{2}+89.724 \times S O C+1224.6 \text { for } S O C \leq 50 \% \\
f_{25}=-10.351 \times S O C^{2}+1083.6 \times S O C+31447 \text { for } 50 \% \leq S O C<70 \% \\
f_{25}=2.6384 \times S O C^{2}-409.55 \times S O C+22035 \text { for } 70 \% \leq S O C \\
\text { C. } \quad \text { Cycling loss }
\end{gathered}
$$

The percentage cycling loss is estimated as in (32):

$$
\begin{gathered}
Q^{\text {cycle }}{ }_{\text {loss }}=B_{1} \times \exp \left(B_{2} \times \text { rate }\right) \times A_{h} \\
B_{1}=a \times T^{2}+b \times T+c \\
B_{2}=d \times T+e
\end{gathered}
$$

Both the pre-exponential factor $B_{1}$ and exponential factor $B_{2}$ are functions of temperature. The values of $a, b, c$ are $8.89 \mathrm{e}-6 \mathrm{Ah}^{-1} \mathrm{~K}^{-2},-0.0053 \mathrm{Ah}^{-1} \mathrm{~K}^{-1}$ and $0.7871 \mathrm{Ah}^{-1}$, respectively. rate is the equivalent number of cycles, calculated as ratio between the discharge current and the current capacity: discharge current/( $\left.N_{\text {cells }} \times C_{\text {cell }}\right) . A_{h}$ is the Ah-throughput, which is the integrated absolute value of the power. rate and $A_{h}$ are directly related: in a simulation with a time step of $1 \mathrm{~s}$, the ratio between the discharged battery current and the battery capacitance is the As (amperesecond)-throughput or rate. The Ah-throughput is thus the ratio between the As-throughput and $3600 \mathrm{sec}$ (rate/3600).

As for the calendar loss the instantaneous cycling loss is depending on the instantaneous temperature and current and is then integrated over time. Differently from the calendar loss, the cycling loss are equal to zero when there is no current flowing.

\section{Test CASE RESUlts}

The battery model above-described is implemented in Matlab-Simulink and it is tested for a two year period simulation considering the average outside temperature of the 2017 and 2018 in Denmark and an average user driver driving $45 \mathrm{~km}$ per day [15]. The battery power profile is shown in Figure 10 subplot 1 for one day long [6]. Subplot 2 shows the SOC during the day and subplot 3 compares the outside and battery temperatures during the $1^{\text {st }}$ July 2017 . The initial SOC is equal to $80 \%$.
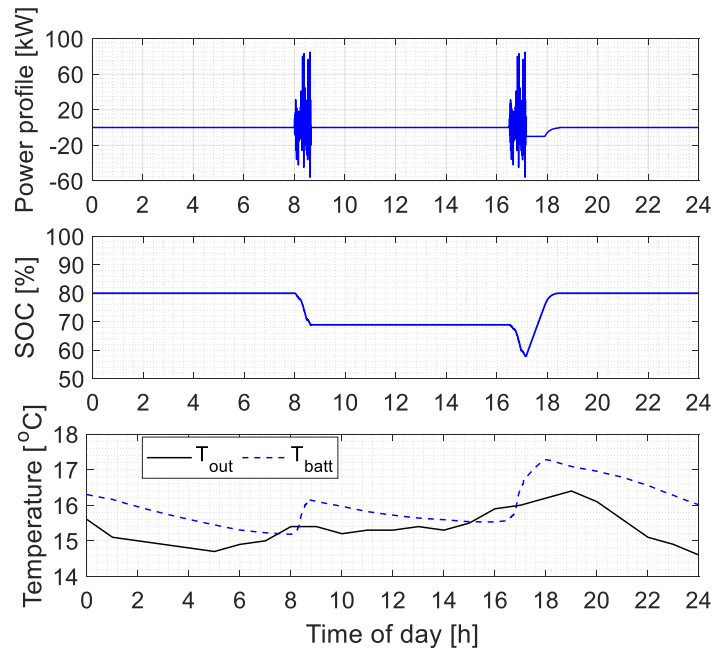

Figure 10. Power profile, SOC and battery-outside temperatures during the 1st July 2017.

The following analysis compares the battery behavior for three initial SOC of the battery: 40,60 and $80 \%$, the rest is kept the same. The initial SOC is an important value also because it determines the final SOC during the day and the average SOC during the year, which in the three cases is approx. 40, 60 and $80 \%$. Considering the same charging/discharging power profile for the 730 days and the outside temperature of the years 2017 and 2018, see Figure 11, calendar aging and cycling loss are provided in the two subplots of Figure 12.

The capacity fade during a two-year period spans between 2.46 and $5.35 \%$ depending on the initial SOC, where most is due to calendar aging. With an initial capacity of $112.6 \mathrm{Ah}$, a user that drives $45 \mathrm{~km} /$ day will have a battery capacity decreased to 106.6 Ah with $80 \%$ SOC, 109.1 with $60 \%$ and 
109.4 with $40 \%$, as shown in Figure 12. The calendar losses drive the total loss, even though they are independent on the battery usage.

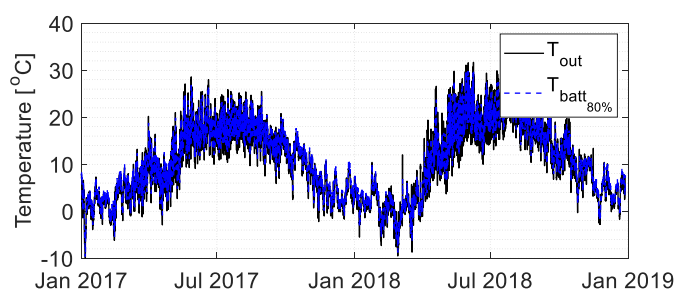

Figure 11. Comparison outside and battery temperature during two-year period 2017-2018.

As in previous analyses the calendar loss are found to be approx. 3-5\% after one year period [3], [6], [16]. The calendar loss is much higher for SOC above $70 \%$, than for $40 \%$ and $60 \%$. This is related to the capacity loss formulation derived from Figure 8. For what concern the cycling loss, the cycles are a small value, due to the considered use of the battery, as just driving. Moreover the battery is large compared to the energy requirement and the EV is idle most of the time. Thus, for this application it is intuitive that the calendar aging is the most relevant loss.

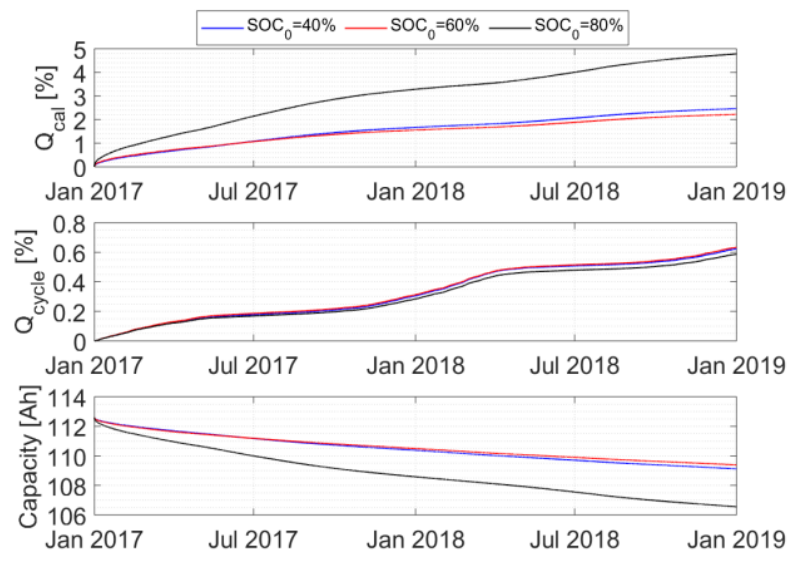

Figure 12. Calendar and cycling loss in percentage, subplot 1 and 2 respectively. Capacity degradation in Ah during two year period.

\section{CONCLUSION}

The present work focused on the development of a model of a storage system for electrical studies in the MatlabSimulink environment. The battery was modelled considering electrical and thermal characterization for the entire battery, based on literature and review. The storage model was realized and described in order to provide general validity, even though, in the present study it was tailored for a specific battery chemistry and size. Capacity aging and cycling loss were modelled on a theoretical formulation base. Considering the temperature profile of years 2017 and 2018 in Denmark and a user driving $45 \mathrm{~km}$ per day, the total capacity loss during two years was found to be $2-5 \%$ of the initial capacity, depending on the initial SOC of the battery. Based on the findings the authors claim that cycling is a small part of the losses of the battery, this induces to think that grid services, which would cause more cycling of the battery, could not cause significant additional wear on the battery life. Future work will consider real test measurements on a battery of the modelled EV to validate the electro-thermal parameters and to perform capacity fade investigations.

\section{ACKNOWLEDGMENT}

The work in this paper has been supported by the research projects ACES (EUDP grant nr: EUDP17-I-12499) and CAR (EU-Interreg grant nr: STHB.03.01.00-SE-S112/17).

\section{REFERENCES}

[1] M. Zheng, B. Qi, and X. Du, "Dynamic model for characteristics of Li-ion battery on electric vehicle," 2009 4th IEEE Conf. Ind. Electron. Appl. ICIEA 2009, pp. 2867-2871, 2009.

[2] B. Wu, Z. Li, and J. Zhang, "Thermal Design for the Pouch-Type Large-Format Lithium-Ion Batteries: I. Thermo-Electrical Modeling and Origins of Temperature Non-Uniformity," J. Electrochem. Soc., vol. 162, no. 1, pp. A181-A191, 2014.

[3] P. Keil et al., "Calendar Aging of Lithium-Ion Batteries," $J$. Electrochem. Soc., vol. 163, no. 9, pp. A1872-A1880, 2016.

[4] D. Wang, J. Coignard, T. Zeng, C. Zhang, and S. Saxena, "Quantifying electric vehicle battery degradation from driving vs. vehicle-togrid services," J. Power Sources, vol. 332, pp. 193-203, 2016.

[5] M. Muratori, "Thermal Characterization of Lithium-Ion Battery Cell," J. Macromol. Sci. Part A - Chem., vol. 22, no. 10, pp. 1429-1441, 1985.

[6] A. Thingvad and M. Marinelli, "Influence of V2G Frequency Services and Driving on Electric Vehicles Battery Degradation in the Nordic Countries Influence of V2G Frequency Services and Driving on Electric Vehicles Battery Degradation in the Nordic Countries," Evs31, 2018.

[7] A. W. Thompson, "Economic implications of lithium ion battery degradation for Vehicle-to- Grid ( V2X ) services," J. Power Sources, vol. 396, no. April, pp. 691-709, 2018.

[8] M. Marinelli, "Wind Turbine and Electrochemical Based Storage Modeling and Integrated Control Strategies," PhD thesis, 2011.

[9] N. S. Pearre, W. Kempton, R. L. Guensler, and V. V. Elango, "Electric vehicles: How much range is required for a day's driving?," Transp. Res. Part C Emerg. Technol., vol. 19, no. 6, pp. 1171-1184, 2011.

[10] X. Shi, J. Pan, H. Wang, and H. Cai, "Battery Electric Vehicles: What is the Minimum Range Required?," Energy, 2018.

[11] J. V Barreras et al., "An improved parametrization method for Liion linear static Equivalent Circuit battery Models based on direct current resistance measurement," 2015 Int. Conf. Sustain. Mobil. Appl. Renewables Technol., pp. 1-9, 2015.

[12] S. C. Chen, C. C. Wan, and Y. Y. Wang, "Thermal analysis of lithium-ion batteries," J. Power Sources, vol. 140, no. 1, pp. 111-124, 2005.

[13] E. Hosseinzadeh, R. Genieser, D. Worwood, A. Barai, J. Marco, and P. Jennings, "A systematic approach for electrochemical-thermal modelling of a large format lithium-ion battery for electric vehicle application," J. Power Sources, vol. 382, pp. 77-94, 2018.

[14] Y. Chen and J. W. Evans, "Thermal analysis of lithium polymer electrolyte batteries by a two dimensional model-thermal behaviour and design optimization," Electrochim. Acta, vol. 39, no. 4, pp. 517-526, 1994.

[15] H. Christiansen and B. Z. Skougaard, "Documentation of the Danish National Travel Survey," vol. 10, no. June, pp. 1-18, 2015.

[16] J. Hicks-Garner et al., "Degradation of lithium ion batteries employing graphite negatives and nickel-cobalt-manganese oxide + spinel manganese oxide positives: Part 1, aging mechanisms and life estimation," $J$. Power Sources, vol. 269, pp. 937-948, 2014. 